CORRECTION

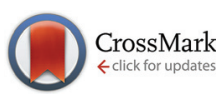

Cite this: Food Funct., 2016, 7, 610

\section{Correction: Rosa canina L. - new possibilities for an old medicinal herb}

Jelena Živković, ${ }^{\star a}$ Dejan Stojković, Jovana Petrović, ${ }^{\mathrm{b}}$ Gordana Zdunić, Jasmina Glamočlija ${ }^{b}$ and Marina Sokovićb

DOI: $10.1039 / c 5 f o 90042 e$

www.rsc.org/foodfunction

Correction for 'Rosa canina L. - new possibilities for an old medicinal herb' by Jelena Živković et al., Food Funct., 2015, DOI: 10.1039/c5fo00820d.
View Article Online

View Journal | View Issue

In the original manuscript, the name of the fifth author was misspelled. The corrected author list is as shown above.

The Royal Society of Chemistry apologises for these errors and any consequent inconvenience to authors and readers. 